\title{
Potential for solar water heating in Zimbabwe
}

\author{
Bothwell Batidzirai ${ }^{\mathrm{a}, \mathrm{b}}$, Erik H. Lysen ${ }^{\mathrm{c}}$, Sander van Egmond ${ }^{\mathrm{c}}$, \\ Wilfried G.J.H.M. van Sark ${ }^{\mathrm{a}, *}$ \\ ${ }^{a}$ Department of Science, Technology and Society, Copernicus Institute for Sustainable Development and Innovation, \\ Utrecht University, Heidelberglaan 2, 3584 CS Utrecht, The Netherlands \\ ${ }^{\mathrm{b}}$ Department of Fuels and Energy, School of Engineering Science and Technology, \\ Chinhoyi University of Technology, P. Bag 7724, Chinhoyi, Zimbabwe \\ ${ }^{\mathrm{c}}$ Utrecht Centre for Energy Research (UCE), Utrecht University, Heidelberglaan 2, 3584 CS Utrecht, The Netherlands
}

Received 3 October 2007; accepted 7 January 2008

\begin{abstract}
This paper discusses the economic, social and environmental benefits from using solar water heating (SWH) in Zimbabwe. By comparing different water heating technology usage in three sectors over a 25 -year period, the potential of SWH is demonstrated in alleviating energy and economic problems that energy-importing countries like Zimbabwe are facing. SWH would reduce coincident electricity winter peak demand by $13 \%$ and reduce final energy demand by $27 \%$, assuming a $50 \%$ penetration rate of SWH potential demand. Up to $\$ 250$ million can be saved and $\mathrm{CO}_{2}$ emissions can be reduced by $29 \%$ over the 25 -year period. Benefits are also present at individual consumer level, for the electricity utility, as well as for society at large. In the case of Zimbabwe, policy strategies that can support renewable energy technologies are already in current government policy, but this political will need to be translated into enhanced practical activities. A multi-stakeholder approach appears to be the best approach to promoting widespread dissemination of SWH technologies.
\end{abstract}

(C) 2008 Elsevier Ltd All rights reserved.

Keywords: Solar water heating; Demand-side management

\section{Contents}

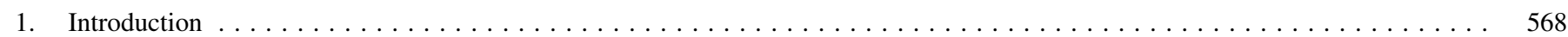

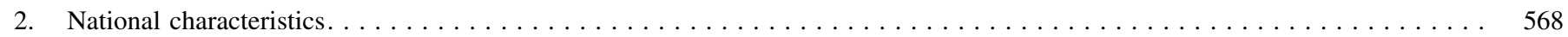

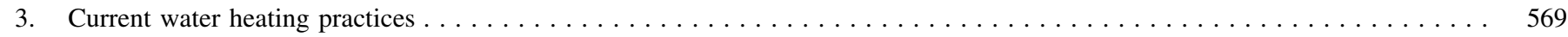

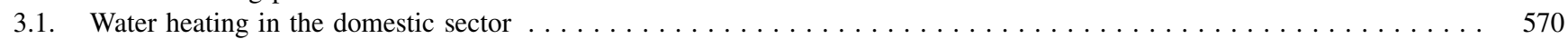

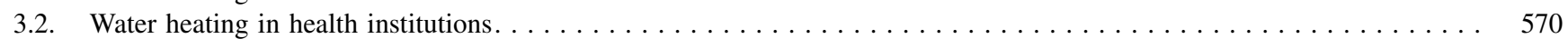

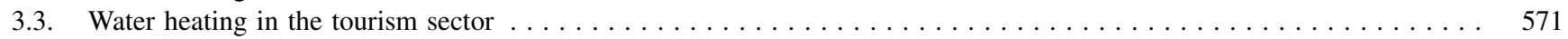

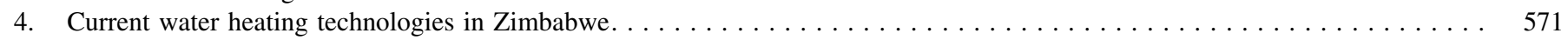

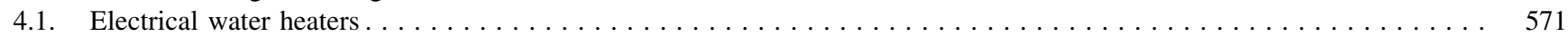

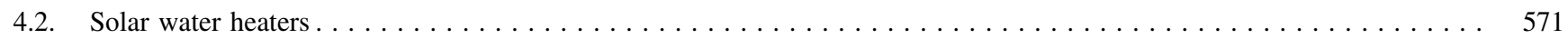

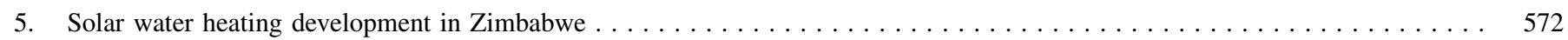

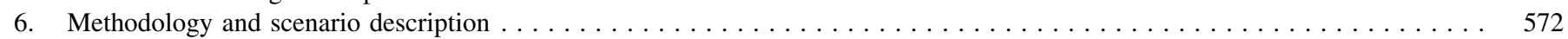

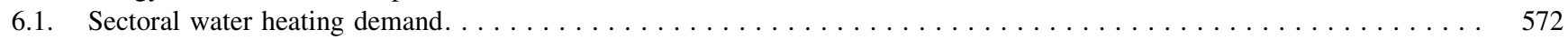

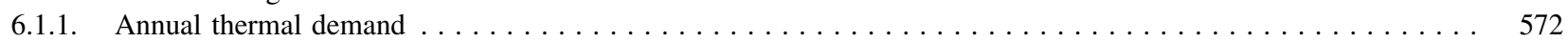

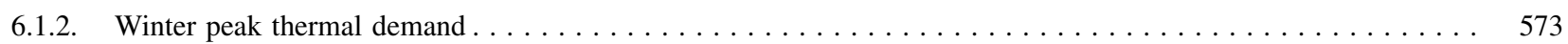

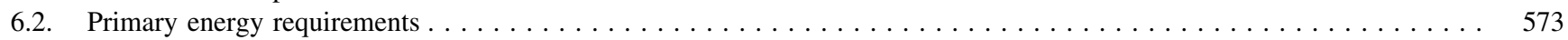

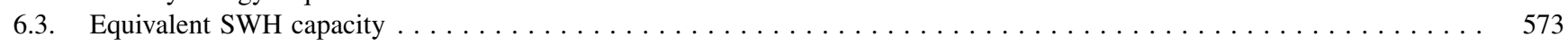

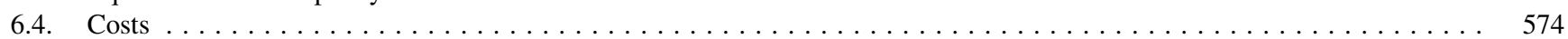

\footnotetext{
* Corresponding author. Tel.: +3130253 7611; fax: +31302537601.

E-mail address: W.G.J.H.M.vanSark@uu.nl (W.G.J.H.M. van Sark).
} 


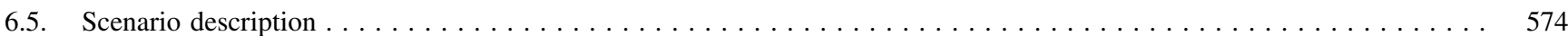

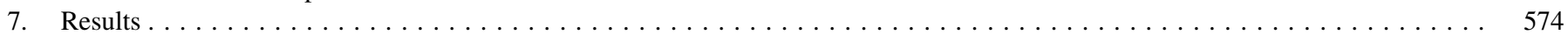

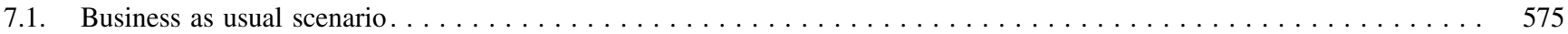

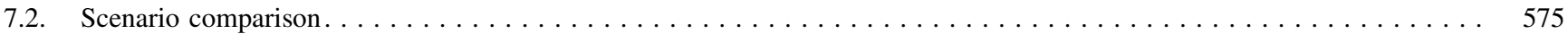

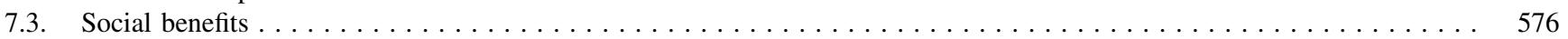

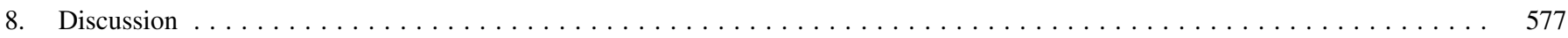

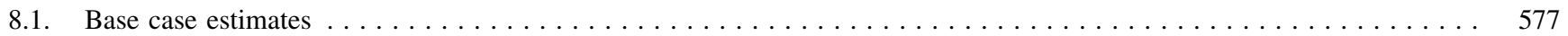

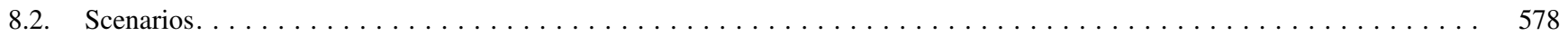

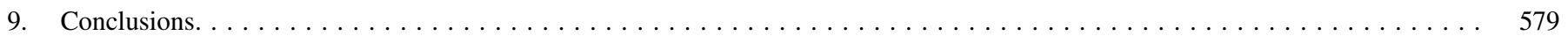

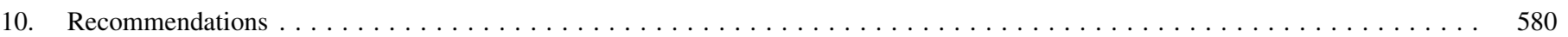

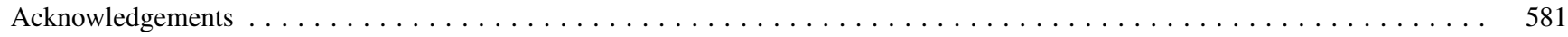

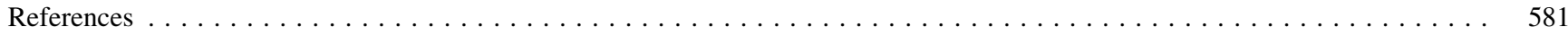

\section{Introduction}

Shortages of modern energy carriers have become a major obstacle to economic growth in Zimbabwe. Energy imports and infrastructure continue to drain scarce convertible currency. Zimbabwe has been importing between $35 \%$ and $60 \%$ of its electricity requirements since 1996 because of inadequate internal power generation capacity. While available power plant capacity declined by at least $15 \%$, maximum demand has increased by $25 \%$ since 1990 . Demand is forecasted to grow from $2000 \mathrm{MW}$ in year 2000-3000 MW by 2010 and over $4000 \mathrm{MW}$ by 2020 [1]. ${ }^{1}$ Around US $\$ 1.5-2$ billion is required to meet investments needed in the power sector over the next decade $[3,4]$. On the other hand, the national electricity utility has accumulated debts with foreign suppliers. IMF [5] estimates the Zimbabwe Electricity Supply Authority (ZESA)s foreign debt to be about US\$240 million. ${ }^{2}$ ZESA has been forced to load shed consumers and this has severely affected industrial, mining and agricultural production. Government measures of preferential allocation of limited hard currency for energy imports are still inadequate to meet full needs. The consequences have been high inflationary pressures and huge economic losses.

Water heating inflicts a significant burden on Zimbabwe's national energy system: it accounts for at least $13 \%$ of the national winter (June-July-August) peak demand for electricity and about $8 \%$ of the annual electricity consumption. It contributes to energy scarcity and unnecessary foreign currency expenditure in the economy. On an individual level, water heating also significantly increases energy expenditure and erodes individual welfare. Additionally, energy scarcity has adverse impact on functioning of the whole economy, especially the productive sectors. In the past, ZESA has operated a ripple control demand-side management (DSM) programme to control domestic water heaters during peaks periods in three major cities and managed to shave off about $7 \%$

\footnotetext{
${ }^{1}$ These estimates are based on a growing economy, but due to continued economic decline in the country, more conservative projections have been developed, e.g. SAPP [2] estimate that maximum demand in Zimbabwe will grow to $2527 \mathrm{MW}$ by 2010 .

${ }^{2}$ In 2005-2006 financial year, ZESA made a loss of US\$372 million [2].
}

of system peak. However, the performance of the ripple control system is reported to be presently poor and this requires costly and extensive refurbishment. It will also cost ZESA US\$177 for each ripple relay receiver [6]. Solar water heating (SWH) offers a partial but significant contribution to resolution of these problems by reducing electricity demand, energy expenditure and improving general societal welfare.

This paper investigates the potential of SWH in alleviating energy and economic problems in a developing country setting by making a comparative evaluation of water heating practices in the domestic, health and tourism sectors in Zimbabwe. The objectives are to demonstrate by scenario analysis the economic, social and environmental benefits that accrue from using solar water heating as opposed to conventional water heating technologies in the period 2005-2030 for the domestic, health, and tourism sector.

This paper is organized as follows: Section 2 describes the national characteristics followed by current water heating practices in Section 3 and technologies in Section 4. The development of SWH in the country is presented in Section 5 after which the methodology for estimating thermal water heating demand as well as SWH scenarios are described in Section 6. Results of scenario analysis are then discussed in Section 7, followed by discussion of the results in Section 8 . Conclusions and recommendations are presented in Sections 9 and 10 , respectively.

\section{National characteristics}

Zimbabwe is located in central southern Africa and lies wholly within the tropics, extending from about $15^{\circ} \mathrm{S}$ to $22^{\circ} \mathrm{S}$ and from $25^{\circ} \mathrm{E}$ to $33^{\circ} \mathrm{E}$. Its territory extends over $390,000 \mathrm{~km}^{2}$ with a population density of about $30 \mathrm{~km}^{-2}$. The climate is generally cool for a tropical country with mean maximum temperatures ranging between 22 and $36{ }^{\circ} \mathrm{C}$ in the hot season (August-November), while mean minimum temperatures range between 10 and $24{ }^{\circ} \mathrm{C}$ in the cool season (May-August). The global annual solar insolation is between 2000 and $2200 \mathrm{kWh} / \mathrm{m}^{2}$ with a $15-25 \%$ insolation variation between the seasons [7].

Zimbabwe's 2002 population census showed that the country has a population of about 11.6 million of which $34 \%$ live in urban areas and $66 \%$ are in rural areas. There are 
about 1.1 million urban households and 1.8 million rural households. On average, a rural household has about 4.4 persons while an urban household has about 3.5 persons. Urban population has been growing at an average rate of $3.9 \%$ since 1992 while national population has grown at only $1.1 \%$ /annum. Beyond 2004, the population is projected to grow by about $0.6 \%$ /annum until 2015 and by $1 \%$ up to 2030 . On the other hand, the number of households is expected to grow by $2.8 \%$ until 2015 and thereafter by $2.3 \%$ until 2030 [5,8], implying smaller future household sizes.

About $41 \%$ of the country's population has access to electricity, i.e., is connected to the national grid. The urban electrification level is about $85 \%$ while the rural population connected to the national electricity grid is about $25 \%$ [9]. Annual per capita electricity consumption declined from $948 \mathrm{kWh}$ in 1990 to $774 \mathrm{kWh}$ in 1998 and increased marginally to $813 \mathrm{kWh}$ in 2005 . About $10.5 \mathrm{TWh}$ of electricity is consumed annually in all sectors [2,10]. Electricity is supplied from a mix of hydro, coal-fired thermal power plants and imports. The development of this mix is shown in Fig. 1. About $80 \%$ of the population are estimated to be living below the poverty datum line and the World Bank classifies Zimbabwe as a low-income country. Real gross domestic product (GDP) declined by almost 30\% from 1997 to 2003 [11]. The economy continued to contract by a further $10.4 \%$ in 2004 and by $4.2 \%$ in 2005 [12]. In the long term, average GDP is expected to increase annually by $1.2 \%$ until 2010, 3.3\% until 2015 and thereafter by $3.6 \%$ until 2030 [13].

Total national final energy consumption (2002) was $343,218 \mathrm{TJ}$ of which nearly $69 \%$ is consumed in the domestic sector and $2 \%$ is consumed in the commercial and public services sector, as illustrated in Fig. 2a. Wood fuel dominates final energy consumption across all sectors (accounting for $71 \%$ of total consumption) followed by petroleum fuels (13\%) and electricity at $11 \%$ (b). In the domestic sector, wood fuel constitutes about $95 \%$ of total energy consumed; electricity contributes only $4 \%$ and petroleum fuels (mainly paraffin) contributes $1 \%$. Commerce and public services use mainly coal and electricity as their source of energy [14]. Fuel choice in the

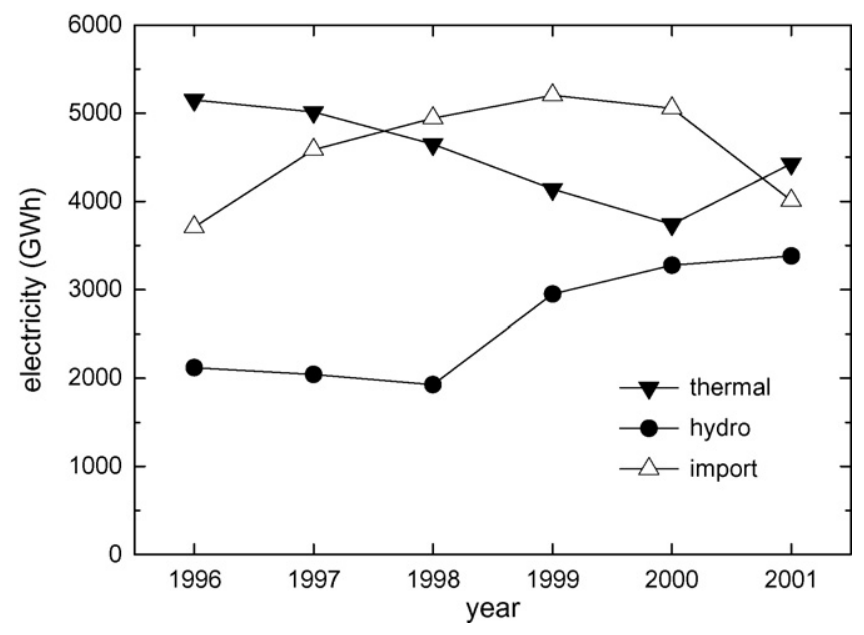

Fig. 1. Historical development of electricity supply mix [1,5].
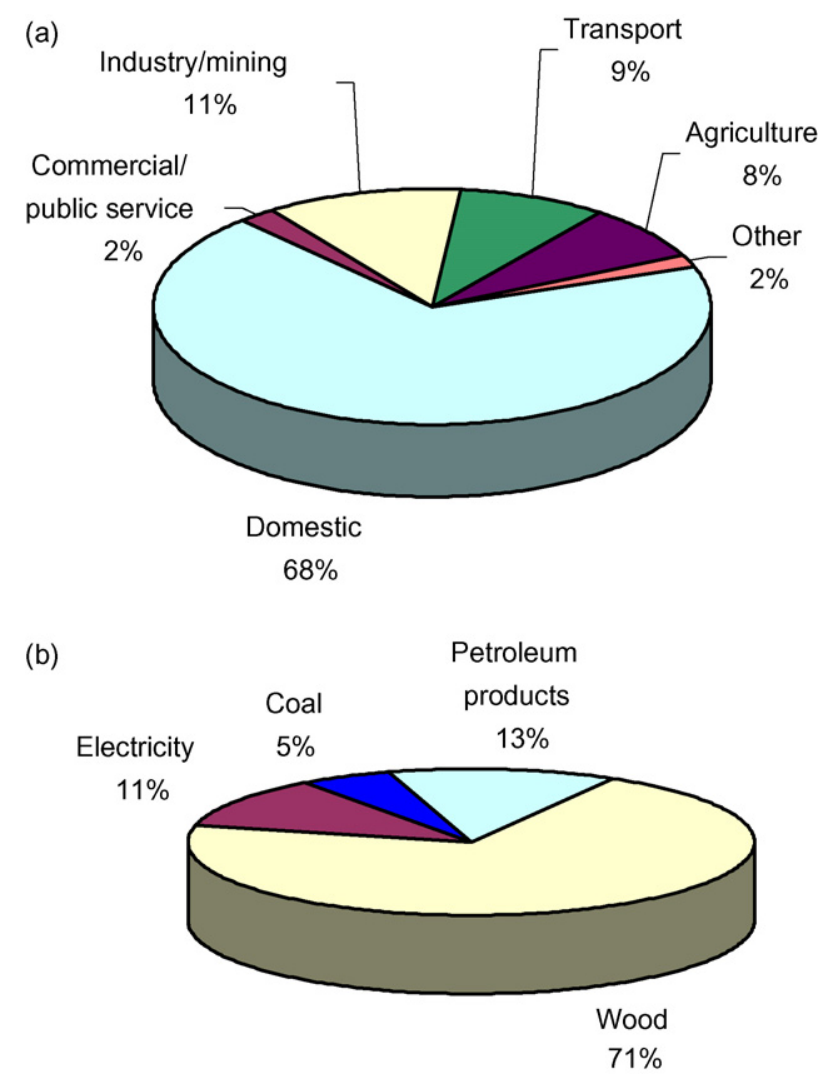

Fig. 2. Distribution of final energy consumption in 2002: (a) per sector and (b) per fuel [14].

domestic sector varies across the rural urban divide. In urban areas, fuel choice depends in general on the level of income and access to alternative forms of energy [15]. However, in rural areas, wood fuel is available at little or no cost and there is no incentive for using alternative energy sources, especially for thermal energy applications.

The domestic sector accounts for $23 \%$ (2442 GWh) of the national electricity consumption and $15 \%(1605 \mathrm{GWh})$ are to the commercial sector. Industry and commerce together consume $63 \%$ of the electricity distributed in the country [14]. In 2000, there were 437,800 domestic electricity consumers in Zimbabwe of which 231,500 can be characterized as high-income consumers; 77,500 are low-income metered and 128,800 are low-income, load-limited consumers [16].

There are 1439 medical institutions in the country of which $57 \%$ are electrified. This includes solar photovoltaic (PV) and diesel genset electrification. The number of hospital beds is estimated to be about 2.3 per 1000 people [17] and hospital bed occupancy is estimated to be about 78\% [18]. There are 412 tourism operators with a total room capacity of about 5600 rooms and over 12,000 person-beds. Average room occupancy in 2000 was $41 \%$ [29].

\section{Current water heating practices}

Water heating is performed using various technologies and fuel types with more diversity found in the domestic sector as described below. 


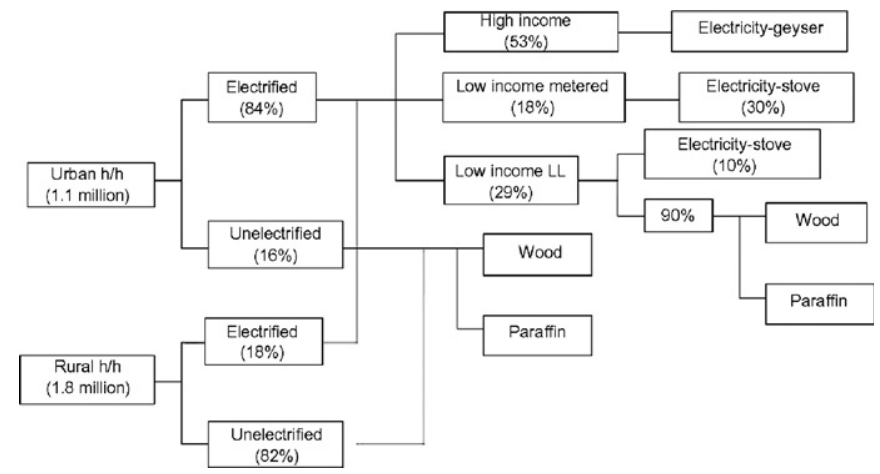

Fig. 3. Structure of domestic water heating patterns by income and location.

\subsection{Water heating in the domestic sector}

The residential sector is made up of electrified and unelectrified households in both urban and rural areas as shown in Fig. 3. Choices for water heating technologies and energy used are based mainly on this distinction as well as other factors such as income levels, accessibility of alternative fuels and individual preferences. About 1 million households ${ }^{3}$ are electrified making up about 437,800 domestic electricity consumers, both in urban and rural areas.

Of the national electrified households, high-income consumers were estimated to be 231,500 (53\%), low-income metered to be $77,500(18 \%)$, and low-income, load-limited consumers to be 128,800 (29\%). These figures include the $85 \%$ urban electrified households and about 80,000 rural domestic consumers. Rural consumers include farms, mines and rural industries. At least 183,000 urban households are unelectrified $[1,16]$.

Water heating in electrified households is by electric storage water heaters in the high-income households and by electric stoves in the low-income households. Wood fuel and paraffin are used for water heating in urban non-electrified households and rural households. Only $10 \%$ of low-income load-limited households use the stove for heating water [20] and the rest use either wood fuel or paraffin. Katihabwa [21] estimated that water heating accounts for $30 \%$ of stove use. Hot water is used mainly for bathing/showering, cooking, dishes and other hygienic purposes.

There are no accurate estimates on the number of installed electric water heaters in the whole country but studies conducted by the Solar Energy Society of Zimbabwe and Nziramasanga in the early 1990s indicated a range between 100,000 and $170,000[20,22]$. We use the later figure because it ties in well with theoretical estimates of water heating demand presented in Section 7. Solar water heaters are also being used in the domestic and tourism sector and estimates indicate that between 4000 and 10,000 systems have been installed in the whole country [1,23].

\footnotetext{
${ }^{3}$ This figure implies that 1 million families have access to electricity but usually more than one family is sharing a common supply (either bulk metered or sharing living premises), and are considered by the electricity utility as a single consumer and hence share the utility bills.
}

Table 1

Annual electricity end-use by household income category

\begin{tabular}{lcrrr}
\hline End use & $\begin{array}{l}\text { High-income } \\
\text { h/h (kWh) }\end{array}$ & $\%$ & $\begin{array}{l}\text { Low-income } \\
\text { h/h }(\mathrm{kWh})\end{array}$ & $\%$ \\
\hline Geyser & 3500 & 39 & 0 & 0 \\
Hot plates (stove) & 2190 & 25 & 2336 & 65 \\
Refrigerator & 876 & 10 & 876 & 24 \\
Freezer & 1095 & 12 & 0 & 0 \\
Lighting & 964 & 11 & 197 & 5 \\
Ironing & 110 & 1 & 110 & 3 \\
Heating & 68 & 1 & 0 & 0 \\
TV & 110 & 100 & 3607 & 100 \\
Total consumption & 8913 & & 300 & \\
Monthly consumption & 742 & & &
\end{tabular}

Source: [26].

High-income electrified households consume on average $742 \mathrm{kWh}$ of electricity per month, $39 \%$ of which is consumed by water heaters. The lower income (metered) households consume on average $300 \mathrm{kWh}$ per month, 65\% of which is consumed by the stove as shown in Table 1. The SADC FINESSE study estimated that urban households consume on average $33 \%$ of their total energy in water heating [22].

Unelectrified urban households use about $7 \mathrm{~kg}$ of wood fuel and 0.031 of kerosene daily, of which $30 \%$ is used for water heating $[21,24]$. The same applies to $90 \%$ of the electrified load-limited households. Rural households consume about $15 \mathrm{~kg}$ of wood fuel/day [26].

\subsection{Water heating in health institutions}

Medical institutions use a diverse range of energy sources including wood, coal, paraffin and electricity for functions such as cooking, heating, sterilizing, refrigeration, lighting and others. There are no documented national hospital energy consumption estimates.

Surveys done by the Department of Energy (Zimbabwe) to estimate energy use in rural hospitals are shown in Table 2. These estimates exclude rural clinics, whose consumption is considered unimportant. Wood estimates were made on the basis of requirements of $15 \mathrm{~kg} /$ patient/day for all purposes.

The larger public hospitals are usually on maximum demand charge electricity supply as their capacities have a significant strain on the electricity network. All consumers who require capacity beyond $300 \mathrm{kVA}$ are classified as maximum demand consumers and a monthly charge is levied for the highest peak demand experienced during the month. This is a demand

Table 2

Estimated energy use in only rural health institutions

\begin{tabular}{ll}
\hline Fuel type & Consumption \\
\hline Wood (tonnes) & 41,440 \\
Electricity (GWh) & 5.53 \\
Coal (tonnes) & 9,500 \\
Kerosene (tonnes) & 2,447 \\
\hline
\end{tabular}

Source: [1]. 
management strategy employed by the national utility to discourage poor load factors and power factors by large consumers. Some of the older and large hospitals such as Harare Central Hospital, although located in urban areas, are still using coal-fired boilers for cooking and laundry.

\subsection{Water heating in the tourism sector}

The tourism industry incorporates hotels, inns, lodges, guesthouses, hostels, chalets and other accommodation facilities used by travellers. For characterization, the sector can be broadly divided into hotels and lodgings. Hotels representing the larger establishments while lodgings represent the smaller ones with fewer than 20 rooms. This distinction is important for comparing energy consumption and investment patterns. Hotels tend to use more energy per occupied room than lodgings and are usually on maximum demand electricity supply [27].

An assessment of electricity use of a 55-room country hotel in Zimbabwe indicated the distribution of electricity use as shown in Fig. 4. Room consumption is dominated by the electric water heater which represents nearly $80 \%$ of electricity use in the room and $54 \%$ of overall facility electricity use. It is important to note that this particular hotel had switched fuels for cooking and ironing from electricity to wood in an attempt to reduce electricity demand. The hotel also had an in-house bakery, from which some products are sold to external customers.

Other fuels used by the tourism industry include LPG for cooking, renewables and diesel generators used for backup in the event of disruptions from the grid. Lodges in remote areas (e.g. Katete and Bumi) use diesel-powered gensets. Renewables such as solar PV and solar water heating are used notably at Elephant Point, Water Wilderness, Chikwenya Safari Lodge, Umkombo and Zengela Game Ranch [19]. In fact, most of the solar water heaters installed since 1980, have been utilized in the tourism industry [1].

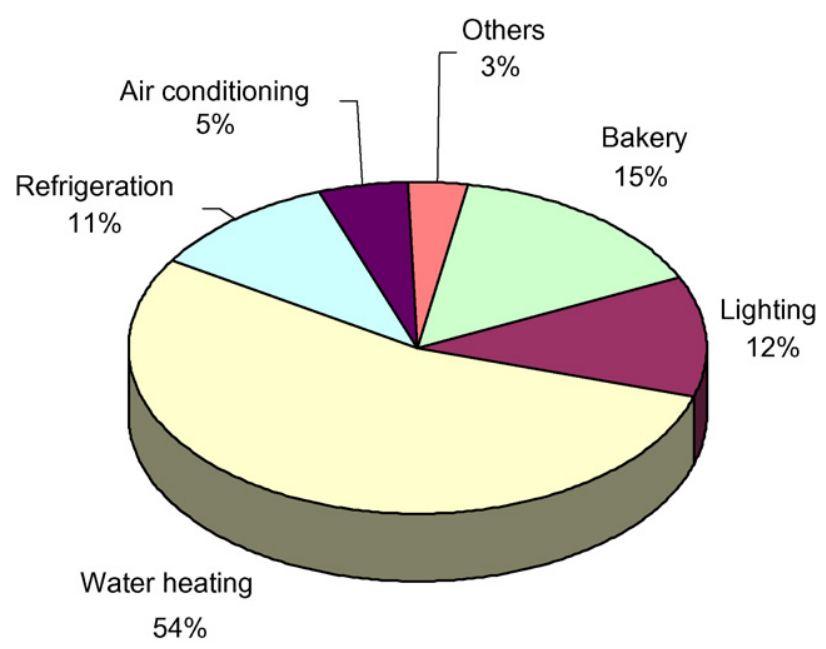

Fig. 4. Results of a 'walk-through' electricity energy audit of a 55-room hotel in Zimbabwe [25].

\section{Current water heating technologies in Zimbabwe}

\subsection{Electrical water heaters}

Electrical water heaters are the dominant water heating technology in Zimbabwe. Commonly known as geysers, these systems are mostly non-pressurised with an integral water reservoir. The heating element is a coil heater located in a pocket at the bottom of the tank. Pressured units are also found in the market and these have an immersion heater element at the bottom of the storage tank. Sizes range from about 151 for small kitchen units to over 90001 for institutional units. These units are usually mounted on the wall or in the roof and are controlled by a thermostat that maintains the temperature of the water at desired temperatures (usually in the range $65-85^{\circ} \mathrm{C}$ ) [22]. Multiple water heating units can be found in affluent households, sometimes up to five units [28].

\subsection{Solar water heaters}

A solar water heater consists of basically a 'collector' for capturing and transferring heat from solar radiation to a working fluid or directly to water. The collector is then connected to a storage tank by a system of pipes. In close coupled or integral systems, the tank and the collector are one unit and distribution pipes delivers hot water to designated loads. Systems can be designed with an auxiliary energy supply, means for circulating and control of water flow through the system.

The most common type of domestic SWH in Zimbabwe is the passive direct 'thermosyphon' system using copper or plastic collectors and an attached insulated hot water storage tank. Both close coupled systems and separate storage tank type of systems are in the market. Their sizes range from 1501 with one collector to 12001 with multiple collectors [29,30]. In this system, the tank is located above the collector, and water will circulate by natural convection whenever solar energy in the collector adds energy to the water in the collector leg and thus establishes a density gradient. Most of the systems come with an auxiliary energy supply (backup electrical element) to maintain hot water in the tank top at some minimum temperature level necessary to meet loads [22]. Canwood [31] reported that one Zimbabwean manufacturer also produces integral collector storage systems. In this system, the storage tank is combined with the collector into a composite glazed, insulated box.

Individual components vary with designs and manufacturers/suppliers. Absorbers range from unglazed extruded polymer panels to sophisticated, well insulated, enhanced transparency collector panels with selective absorber surfaces. The former are usually used for low temperature applications and the later (which are not common) for high temperature applications up to $90{ }^{\circ} \mathrm{C}$. The most common collector panel consists of copper tubes mounted on a back plate which are painted black and positioned behind a glass cover. Some low cost units have no glass cover [20,22]. SWH storage tanks are commonly made from copper, but a wide variety of materials 
are also used such as plastic, stainless steel, glass-lined steel tanks and fibreglass. Larger systems have corrosion resistantlined steel tanks.

\section{Solar water heating development in Zimbabwe}

Solar water heaters have been produced in Zimbabwe since the 1970s supplying mainly the high-income households and the tourism sector. Poor performance of some designs affected growth of SWH in the 1980s but there was renewed interest after the electricity shortages around 1991/1992. After 1992, low electricity prices may have hampered further development in the 1990s [1]. However, a lot of interest in SWH remained in the midto late-1990s piggybacking on the successful promotion of solar PV through the UNDP/GEF Solar PV Pilot project.

Solar water heating is listed as one of the priority projects under the government's "National Renewable Energy Programme (1996-2005)". However, emphasis is given to PV for lighting. Similarly the "Rural Electrification Programme" also dwells on solar PV and only lists SWH as a potentially valuable technology.

Most of the SWH systems in Zimbabwe are imported from Europe, America, Asia, Australia and South Africa. There is limited local production and assembling, only three local manufacturers and three importers of system kits for local assembly were in operation in 1998. Local producers still need to import some components such as tank materials usually from South Africa [1,20]. At least four companies are active in the supply and installation of SWH. ${ }^{4}$

A number of initiatives have been undertaken in Zimbabwe to promote SWH. These include the Austrian supported project run by Domestic Solar Water Heating Ltd., the Dutch/UNDP supported SADC FINESSE activities, the Zimbabwe government's own SWH program under the Renewable Energy Programme and other private initiatives.

The Austrian supported SWH programme in Zimbabwe promoted the development and manufacture of affordable thermosyphon SWHs. It has trained craftsmen and developed SWHs using mainly local materials. About 230 SWH systems have been successfully installed to date in homes, schools and rural clinics through the programme, and the trained technicians are now carrying out installations on their own [30].

\section{Methodology and scenario description}

In order to estimate the potential of solar water heating, first an estimate is needed of the total energy demand and winter peak demand for water heating in the three selected sectors. Subsequently, solar thermal requirements for substitution of this demand are determined. The potential of SWH is then evaluated and shown in relation to the need for additional electricity generation capacity over the next 25 years. This way

\footnotetext{
${ }^{4}$ These include Solahart which imports and supplies systems as part of a dealer network of Solahart (Australia), Solarmatics, Solar Impact and Domestic Solar Heating Ltd.
}

comparative estimates are made of the primary energy requirements for meeting water heating demand either by conventional power plants or SWHs.

\subsection{Sectoral water heating demand}

\subsubsection{Annual thermal demand}

Two approaches, one top-down and one bottom-up, were used to determine the water heating demand in the domestic sector. The first approach is based on a UNEP study [26] in which electrified households are classified into three categories: (1) high-income group, who own electric water heaters; (2) low-income group with metered electricity supply, who use electric stoves to heat water; and (3) low-income group with load-limited electricity supply, who partly use stoves as well as wood and paraffin to heat water, see also Fig. 3. The UNEP study estimated annual electricity consumption for all electricity end-uses including electric water heating in highincome households. These estimates were then used as a basis for approximating electricity use for water heating in the highincome category. Additional assumptions were used for the low-income load-limited households using stoves to heat water and those who use other fuels.

Additionally, it is assumed that unelectrified urban households have the economic potential to adopt SWH since they already are purchasing energy to meet their hot water energy requirements. In contrast, most rural unelectrified households use mostly firewood to meet their thermal energy needs and use kerosene for lighting. This group does not buy firewood and therefore has low economic potential for adopting SWH technology.

Based on the household characteristics and assumptions, we estimate the total household water heating thermal energy demand $E_{\mathrm{th}, \mathrm{d}}$ using:

$E_{\mathrm{th}, \mathrm{d}}=\sum_{i, j, k} H_{i} E_{i, j} f_{i, j} f_{i, k} \eta_{k}$

where $H_{i}$ is number of households by category $i ; E_{i, j}$ is average annual energy consumption per type $j$ used by household category $i$ (electricity, wood, paraffin); $f_{i, j}$ is fraction of energy type $j$ used for water heating; $f_{i, k}$ is fraction of households using water heating device $k$ (electric stove, hot plate); and $\eta_{k}$ is the efficiency of water heating device $k$. We use efficiencies from [34], i.e., 0.9, $0.65,0.25$, and 0.4 for the efficiency of an electric geyser, hot plate, wood stove, and paraffin stove, respectively. The thermal demand $E_{\text {th,d }}$ can be split up per energy source, i.e., electricity $E_{\mathrm{th}, \mathrm{d}, \mathrm{e}}$, wood fuel $E_{\mathrm{th}, \mathrm{d}, \mathrm{w}}$, and paraffin $E_{\mathrm{th}, \mathrm{d}, \mathrm{p}}$ as follows:

$E_{\mathrm{th}, \mathrm{d}}=E_{\mathrm{th}, \mathrm{d}, \mathrm{e}}+E_{\mathrm{th}, \mathrm{d}, \mathrm{w}}+E_{\mathrm{th}, \mathrm{d}, \mathrm{p}}$

The second approach of estimating thermal energy demand for water heating is based on daily hot water requirements ${ }^{5}$ per

\footnotetext{
${ }^{5}$ We assume uniform weather conditions for the whole country, but in reality annual average temperatures in the eastern highlands are $15^{\circ} \mathrm{C}$ while those in low lying areas such as Kariba are $25^{\circ} \mathrm{C}$. Hence there is higher hot water demand in the former and even preference for cold water in the latter.
} 
person from which the thermodynamic energetic requirements are estimated. The total thermal demand $E_{\mathrm{th}, \mathrm{d}}$ is then obtained using

$E_{\mathrm{th}, \mathrm{d}}=\sum_{k} W_{k} P_{k} \Delta T c_{p} \eta_{k}$

where $W_{k}$ is the hot water requirement per person per heating device (30 1/capita/year); $P_{k}$ number of persons; $\Delta T$ temperature difference between cold and hot water $(18 \mathrm{~K}) ; c_{p}$ is the specific heat capacity of water $(4.19 \mathrm{~kJ} /(\mathrm{kg} \mathrm{K}))$. Here, a distinction is made between electric and wood stoves, which also leads to a different hot water requirement $W_{k}$.

The estimation of the thermal energy demand in the health sector is based on designs and empirical data from an Indonesian hospital water heating project [41]. The water heating energy demand $E_{\mathrm{th}, \mathrm{h}}$ is determined from

$E_{\mathrm{th}, \mathrm{h}}=B \beta W_{\mathrm{b}} \mathrm{SEC} \eta$

where $B$ is the total number of hospital beds in the country; $\beta$ the average annual bed occupancy; $W_{\mathrm{b}}$ the average annual water demand per patient/bed $\left(10.9 \mathrm{~m}^{3}\right)$; SEC the average specific electricity use per litre of water (estimated at $0.03 \mathrm{kWh} / \mathrm{l}) ; \eta$ is efficiency of water heating device.

We assume that only electricity is used to meet water heating thermal demand, which enables us to estimate the total demand based on individual hot water requirements without allocating specific energy carriers. In reality, however, hospitals use multiple energy sources and technologies to meet hot water energy needs including coal- and wood-fired boilers.

For the tourism sector the thermal energy demand is estimated assuming that water heating demand per person in a large hotel is approximately equivalent to that for a single person of for instance, a guesthouse. Although the tourism industry has a diverse range of accommodation facilities of which we have broadly classified as hotels and lodgings, it simplifies our analysis to consider the total room capacity available in the sector. The differences between the larger facilities that use boiler units of several thousand litres capacity and smaller facilities that have individual heating units per room is accounted for by assuming that each room has a 1501 equivalent water heater. Thus, we estimate the total thermal energy demand for the sector $E_{\mathrm{th}, \mathrm{t}}$ as follows:

$E_{\mathrm{th}, \mathrm{t}}=R \rho W_{\mathrm{r}} \mathrm{SEC} \eta$

where $R$ is the total capacity of rooms in the sector (person rooms); $\rho$ the average room occupancy; $W_{\mathrm{r}}$ is the average annual hot water demand per room at full occupancy $\left(18.1 \mathrm{~m}^{3}\right)$.

Based on the above the total annual heating demand $E_{\mathrm{th}}$ is given as

$E_{\mathrm{th}}=E_{\mathrm{th}, \mathrm{d}}+E_{\mathrm{th}, \mathrm{h}}+E_{\mathrm{th}, \mathrm{t}}$

while the annual heating demand met by electricity $E_{\mathrm{th}, \mathrm{e}}$ equals

$E_{\mathrm{th}, \mathrm{e}}=E_{\mathrm{th}, \mathrm{d}, \mathrm{e}}+E_{\mathrm{th}, \mathrm{h}}+E_{\mathrm{th}, \mathrm{t}}$

as the heating for the health and tourism sector is provided by electricity only.

\subsubsection{Winter peak thermal demand}

The winter peak demand imposed on the electricity network by water heating $P_{\mathrm{th}, \mathrm{d}, \mathrm{w}}$ is calculated with

$P_{\mathrm{th}, \mathrm{d}, \mathrm{w}}=\sum_{i} a_{i} D_{i}$

where $a_{i}$ is the amount of electrical heating devices (geyser, stove) for all households; $D_{i}$ is average diversified demand contribution per electrical heating device to winter peak demand and is based on empirical studies conducted to assess the contribution of electrical water heating to coincident peak winter demand [32].

Similarly, coincident winter peak demand for hospitals $P_{\text {th,h,w }}$ and hotels $P_{\text {th,t,w }}$ is estimated using the same principle as with households, but we use equivalent number of appliances derived from estimated appliances per patient and hotel guest, respectively. This is done because the ratio of patient and hotel guest per heater unit is higher and high capacity units are used to cater for many patient and hotel guest. Additionally, hot water is used for other purposes such as centralized laundry, cooking and cleaning.

The total winter peak demand is given as

$P_{\mathrm{th}, \mathrm{w}}=P_{\mathrm{th}, \mathrm{d}, \mathrm{w}}+P_{\mathrm{th}, \mathrm{h}, \mathrm{w}}+P_{\mathrm{th}, \mathrm{t}, \mathrm{w}}$

\subsection{Primary energy requirements}

Primary energy $\mathrm{PE}_{\mathrm{e}}$ requirements for the thermal energy demand met by electricity generated from coal is derived from the aggregation of electricity demand for water heating in all three sectors $\left(E_{\mathrm{th}, \mathrm{e}}\right)$ and conversion to primary energy taking into account conversion and distribution losses:

$\mathrm{PE}_{\mathrm{e}}=\frac{E_{\mathrm{th}, \mathrm{e}} f_{t}(1+L)}{\eta_{\mathrm{c}}}$

where $f_{t}$ is the fraction of electricity generated from coal $(0.57)$; $\eta_{\mathrm{c}}$ the efficiency of the coal thermal power plant $(0.32) ; L$ is the transmission loss factor (0.15). Data is from [33].

The primary energy demand for the other carriers $\left(\mathrm{PE}_{\mathrm{wf}}\right.$ for wood fuel, $\mathrm{PE}_{\mathrm{p}}$ for paraffin) are calculated with

$\mathrm{PE}_{\mathrm{wf}}=A_{\mathrm{wf}} \mathrm{HHV}_{\mathrm{wf}} \eta_{\mathrm{ws}}$

$\mathrm{PE}_{\mathrm{p}}=A_{\mathrm{p}} \mathrm{HHV}_{\mathrm{p}} \eta_{\mathrm{ps}}$

where $A_{\mathrm{wf}}$ is the amount of wood fuel; $\mathrm{HHV}_{\mathrm{wf}}$ higher heating value of wood fuel $(16 \mathrm{MJ} / \mathrm{kg}) ; \eta_{\mathrm{ws}}$ efficiency of wood fuel stove (0.25); $A_{\mathrm{p}}$ is the amount of paraffin; $\mathrm{HHV}_{\mathrm{p}}$ higher heating value of paraffin $(38 \mathrm{MJ} / \mathrm{l}) ; \eta_{\mathrm{ps}}$ is the efficiency of paraffin stove (0.4). Data are from [34].

The total amount of primary energy PE thus is

$\mathrm{PE}=\mathrm{PE}_{\mathrm{e}}+\mathrm{PE}_{\mathrm{w}}+\mathrm{PE}_{\mathrm{p}}$

\subsection{Equivalent SWH capacity}

Given the thermal demand estimated in Eq. (6) the equivalent solar water heating capacity $(S)$ required to meet 
this demand was assessed using

$S=\frac{f_{\mathrm{s}}}{G \eta_{\mathrm{c}} \eta_{\mathrm{s}}} \sum_{i} E_{\mathrm{th}, i}$

where $E_{\mathrm{th}, i}$ is the thermal demand for sector $(i) ; f_{\mathrm{s}}$ the solar fraction (annual hot water demand met by solar irradiation, $0.75) ; G$ the effective mean yearly solar radiation $(2100 \mathrm{kWh} /$ $\left.\mathrm{m}^{2}\right) ; \eta_{\mathrm{c}}$ the efficiency of the solar collector $(0.6) ; \eta_{\mathrm{s}}$ is the efficiency of the SWH system (0.85, includes distribution/ storage efficiencies). ${ }^{6}$

\subsection{Costs}

The economic cost benefit analysis is based on life cycle costing in which all investments are discounted over their lifetime. The concept of present value is used to equate all cash flows occurring during the period under analysis. Comparison of scenarios is then based on the net present value (NPV) as defined as

$\mathrm{NPV}=I+\sum_{i=1}^{L} \frac{C_{i}}{(1+r)^{L}}$

where $I$ is the initial capital investments; $C_{i}$ the aggregate costs incurred in year $(i) ; r$ the social discount rate $^{7} ; L$ is the lifetime of the project.

In the present paper all costs are given in year 2000 US\$. Environmental impacts considered here consist of greenhouse gas emissions associated with generation of power from coal and are calculated in $\mathrm{CO}_{2}$ equivalents.

\subsection{Scenario description}

Using 2000 as the base year, four scenarios were developed that show the costs and benefits of meeting water heating demands using different technologies over a 25 -year period. The first scenario assumes a business as usual (BAU) projection where current water heating practices remain unchanged and energy shortfalls are met by imports. The second scenario is a variation of the business as usual scenario where additional internal coal thermal power plant (CTPP) capacity is established to meet increased energy demand. The third (SWH-I) and fourth (SWH-II) scenarios assume the gradual introduction of solar water heaters, which displace the different water heating systems currently in use, see Fig. 5. The third scenario (SWH-I) assumes that electrical backup energy would

\footnotetext{
${ }^{6}$ Tropical climates generally achieve solar fractions of 80 to $100 \%$, but we use a conservative estimate of $75 \%$ [36]. Average efficiency of a SWH is $60 \%$ while average system efficiency of a SWH system is $85 \%$ [35].

${ }^{7}$ The social discount rate is used in economic analysis of energy projects to represent the opportunity cost of capital or return on investment in alternative projects. It is different from market discount rates used in financial analysis. Social discount rates are used for national projects and in this regard, investments in the energy sector are of national dimension and not based on private financial discounting. Since SWHs are purchased by private individuals, this study therefore assumes a national program to promote SWH. A $10 \%$ discount rate is used in this study.
}

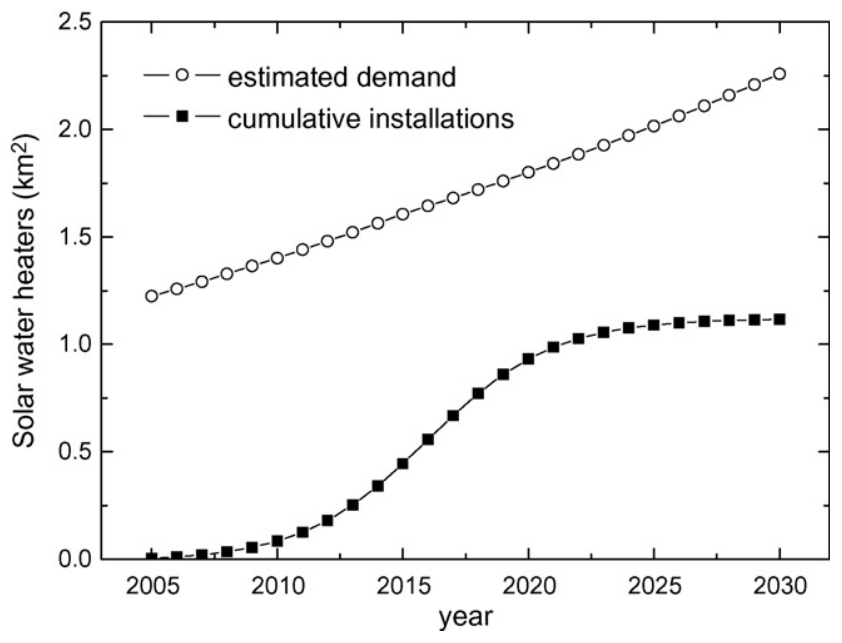

Fig. 5. Diffusion of solar water heaters $\left(\mathrm{km}^{2}\right)$.

come from new power plants while the fourth scenario (SWHII) uses imported power for backup. In order not to overestimate the initial market uptake of solar water heaters, we use a logistic function to estimate the diffusion of solar water heating technology into the market, as depicted in Fig. 5. The following equation describes the function:

$y(t)=\frac{A}{1+\exp \left[-b\left(t-t_{\mathrm{m}}\right)\right]}$

where $y(t)$ is the cumulative number of SWH units installed; $A$ is the upper limit (market saturation value), $b$ the diffusion rate, $t_{\mathrm{m}}$ the time (in years) at which the curve reaches half the asymptote value $(A)$, i.e., where the derivative of the curve is at is maximum.

The choice of parameters used in constructing realistic diffusion trends were based on firstly the practical limitation that not all consumers in the selected subsectors will adopt the technology. We have assumed that we can achieve $50 \%$ of the potential market. Secondly, there is limited technical capacity to manufacture, install and service large volumes of SWH systems and therefore, diffusion rates are limited to available capacity which is assumed to grow with experience and increase in business

\section{Results}

In the base year (2000), aggregate annual electricity consumption for water heating in all three sectors was estimated to be about $890 \mathrm{GWh}$ (or 3.2 EJ). Total wood fuel and paraffin demand were about 380 ktonnes $(6.0 \mathrm{EJ})$ and $600 \mathrm{~m}^{3}$ (23 TJ)/year, respectively, as shown in Table 3. Each electrical water heater in the 231,000 high-income households consumes on average $10 \mathrm{kWh} /$ day. It contributes about $1.1 \mathrm{~kW}$ of diversified demand to the electricity winter peak demand [32], which therefore totals about $250 \mathrm{MW}$. Adding contributions from other households and the tourism and health sector leads to a total coincident winter peak demand due to water heating of about $275 \mathrm{MW}$. Aggregate thermal demand for water 
Table 3

Breakdown of annual energy consumption for water heating in base year (hh: households)

\begin{tabular}{|c|c|c|c|c|c|}
\hline Subsector & $\begin{array}{l}\text { Electricity } \\
(\mathrm{GWh})\end{array}$ & $\begin{array}{l}\text { Wood fuel } \\
\text { (ktonnes) }\end{array}$ & $\begin{array}{l}\text { Paraffin } \\
\left(\mathrm{m}^{3}\right)\end{array}$ & $\begin{array}{l}\text { Total energy } \\
\text { use }(E J)\end{array}$ & $\begin{array}{l}\text { Electricity peak } \\
\text { demand (MW) }\end{array}$ \\
\hline High-income hh & 816.4 & - & - & 2.939 & 254 \\
\hline Low-income metered hh & 54.5 & - & - & 0.196 & 10.3 \\
\hline Low-income load-limited hh & 8.3 & 95 & - & 1.551 & 1.7 \\
\hline Unelectrified hh & - & 284 & 602 & 4.565 & - \\
\hline Subtotal domestic & 880 & 379 & 602 & 9.252 & 266 \\
\hline Tourism sector & 2.9 & - & - & 0.011 & 2.5 \\
\hline Health sector & 7.6 & - & - & 0.027 & 8.4 \\
\hline Total & 890 & 379 & 602 & 9.290 & 277 \\
\hline
\end{tabular}

heating met by electricity was estimated to be $2.8 \mathrm{EJ} / \mathrm{annum}$. Of this demand $98 \%$ is accounted by the domestic sector of which $93 \%$ is accounted by the high-income households. Hospitals account for the other $0.8 \%$ and hotels only $0.3 \%$. Total thermal demand for water heating in 2000 in all sectors was estimated to be about 4.4 EJ. Of this demand $65 \%$ was met by electricity while $35 \%$ was met by wood fuel. Paraffin represented less than $1 \%$ of the energy used to meet water heating thermal demand. Total primary energy requirements for water heating were estimated to be about $6.5 \mathrm{EJ}$ of coal, 6.1 EJ of wood fuel and $23 \mathrm{TJ}$ of paraffin giving a total of about $12.6 \mathrm{EJ} /$ year.

SWH system size requirements were estimated on the basis of a conservative solar fraction of 0.75 [36] and average annual solar insolation of $2100 \mathrm{kWh} /\left(\mathrm{m}^{2}\right.$ year $)$ [7]. For the base year 2000 , the required collector area is about $1.03 \mathrm{~km}^{2}$, based on a solar collector efficiency of $60 \%$ and a SWH system efficiency of $85 \%$. A more thorough analysis on energy delivery from various types of solar collectors confirms these simple assumptions [37]. The total thermal load to be met by solar energy was estimated to be about 3.3 EJ. Each SWH reduces coincident peak demand by $0.7 \mathrm{~kW}$. Hence peak winter demand for electrical backup was estimated to be about $100 \mathrm{MW}$ and coal usage was about $2.8 \mathrm{EJ}$ or about $110 \mathrm{ktonnes/year.}$

\subsection{Business as usual scenario}

Using a projected population growth of 1\%/annum, 5.9 million households in 2030 are expected, while the number of domestic electricity consumers is expected to increase to about 932,000 and electricity demand for water heating is estimated to reach nearly $1900 \mathrm{GWh} /$ annum. Annual wood fuel and paraffin use in water heating increase to be about 770 ktonnes and $1300 \mathrm{~m}^{3}$, respectively. The number of beds per 1000 people in health institutions is estimated to increase to 4.6 in 2030 as a result of population growth. Hotels room occupancy is expected to increase to about $70 \%$. Annual electricity demand for water heating in the health and tourism sector is estimated to grow to 13.2 and 4.4 GWh in 2030 , respectively, or less than $1 \%$ of the total domestic demand. In all three sectors, electricity demand for water heating is projected to grow to about $1900 \mathrm{GWh}$ in 2030, see also [38].

Coincident winter peak demand due to water heating is estimated to increase to about $590 \mathrm{MW}$ in 2030. Total energy requirements including electricity imports, wood fuel and paraffin will therefore increase by about $109 \%$ to $20.4 \mathrm{EJ}$ in 2030. Note that Dube [39] estimates electricity demand savings of around $200 \mathrm{MW}$ as a result of installing SWHs as a means to realize demand-side management.

Investment in electrical water heaters was projected to grow to about $\$ 76$ million by 2030 based on unit costs of about $\$ 150$. Annual electricity imports costs to cover water heating thermal demand were projected to increase to about $\$ 74$ million in 2030, while wood fuel and paraffin costs are estimated to grow to about $\$ 19.5$ million and $\$ 0.95$ million, respectively. The cumulative discounted costs of the BAU scenario amount to about $\$ 510$ million, using a social discount rate of $10 \%$ and lifetime of 25 years. Cumulative $\mathrm{CO}_{2}$ emissions from water heating are estimated to be 68,000 tonnes for the 25 -year period (2005-2030).

\subsection{Scenario comparison}

Table 4 summarises the key features of the four scenarios in terms of energy use, costs and environmental emissions. The SWH scenarios lead to $27 \%$ less energy consumption compared

Table 4

Comparative summary of four scenarios

\begin{tabular}{|c|c|c|c|c|}
\hline & \multicolumn{4}{|l|}{ Scenario } \\
\hline & BAU & СТРP & SWH-I & SWH-II \\
\hline \multicolumn{5}{|c|}{ Cumulative energy use in period 2005-2030 (EJ) } \\
\hline Electricity & 133.6 & 133.6 & 95.4 & 95.4 \\
\hline Wood fuel & 249.0 & 249.0 & 183.6 & 183.6 \\
\hline Paraffin & 0.96 & 0.96 & 0.07 & 0.07 \\
\hline Total & 383.6 & 383.6 & 279.7 & 279.7 \\
\hline Energy savings & - & - & 103.9 & 103.9 \\
\hline \multicolumn{5}{|c|}{ Cumulative emissions in period 2005-2030 (megatonnes) } \\
\hline $\mathrm{CO}_{2}$ equivalent & 0.068 & 43.2 & 30.810 & 0.017 \\
\hline $\mathrm{SO}_{2}$ equivalent & 0 & 0.164 & 0.117 & 0 \\
\hline Particulates & 0 & 0.116 & 0.083 & 0 \\
\hline Emission savings $\left(\mathrm{CO}_{2}\right)$ & 43.13 & - & 12.39 & 43.18 \\
\hline \multicolumn{5}{|c|}{ Cumulative costs in period 2000-2030 (million \$) } \\
\hline Cumulative NPV & -508 & -705 & -610 & -455 \\
\hline Costs savings (wrt BAU) & 0 & -197 & -102 & +53 \\
\hline Costs savings (wrt CTPP) & 197 & - & 95 & 250 \\
\hline
\end{tabular}


to the BAU and CTPP scenarios and the SWH scenarios realise savings of about $104 \mathrm{PJ}$ of final energy use over the period 2005-2030 assuming a 50\% market penetration and a modest diffusion rate (Fig. 5). Non-renewable coal resources amounting to about 3 million tonnes can potentially be saved. A higher diffusion rate and a higher market penetration results in 54\% savings of the BAU scenario or about 210 PJ (for $80 \%$ market penetration).

Fig. 6 shows the cumulative discounted costs of each scenario. The two scenarios that involve establishment of internal power generating plants have the highest costs compared to the importing scenarios. Economic savings are apparent for both SWH scenarios, with about $\$ 100$ million savings for the power plant trajectory and about $\$ 53$ million for the importing scenario. SWH can also result in discounted cost savings of between $\$ 95$ million and $\$ 250$ million depending on the source of backup electricity. Likewise, quicker market transformation and higher market penetration can result in savings of between about $\$ 140$ million and $\$ 300$ million. Between $60 \%$ and $85 \%$ of these costs are foreign related [6]. In contrast, $90 \%$ of the components of SWHs are local and only $10 \%$ are foreign related [1].

The SWH-I scenario results in 29\% (12.4 Mtonnes) cumulative $\mathrm{CO}_{2}$ equivalent emissions savings compared to the CTPP scenario over the 25 -year period. Emissions can be reduced by up to $58 \%$ by quicker and higher market penetration of SWHs.

The SWH-II scenario is the cheapest option since it avoids investments in new power generation capacity and relies on imported electricity. However, the importing trajectories are dependent on availability of excess capacity within the regional power pool and very sensitive to electricity import prices. There are also worries about self-sufficiency and national energy security. The advantage of a SWH scenario where backup electricity is imported is that in the long term, the country becomes less dependent on imported electricity. Backup for solar water heating is only necessary during off-peak hours when electricity prices are favourable. Peak demand is reduced by $64 \%$ per water heating device and nationally peak demand

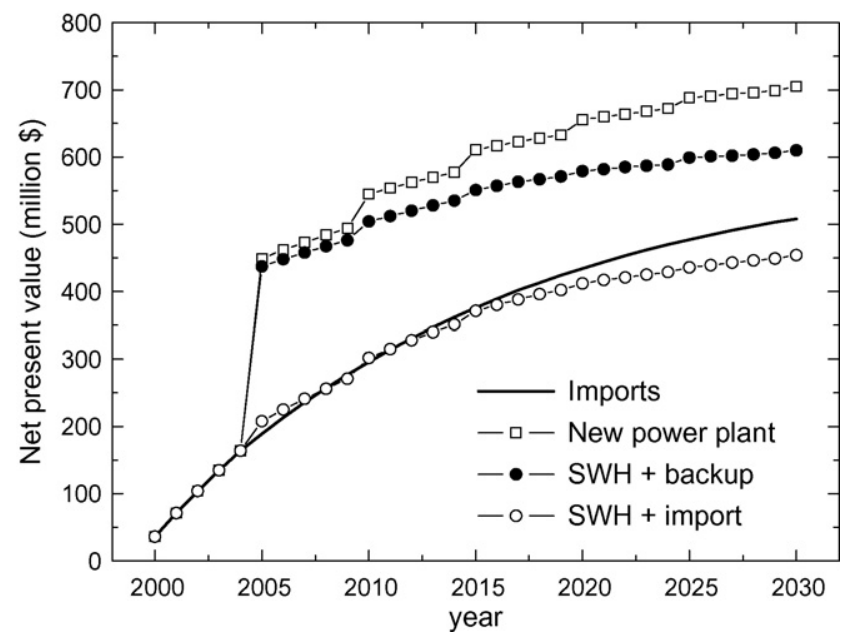

Fig. 6. Comparison of cumulative costs for all water heating scenarios. can be reduced from $13 \%$ to about $5 \%$ with significant benefits to the utility and the whole economy.

The SWH-I scenario requires significant investment in internal generation capacity. This plant capacity is slowly substituted by installed SWH capacity over the years and the excess power can be used elsewhere in the economy.

Local generation has an advantage as far as national energy security is concerned, but the foreign components of initial investment costs are high (around 60-70\%). Maintenance and rehabilitation of plants also involve substantial amounts of foreign currency, for example $86 \%$ of the costs of refurbishing small thermal power plants are foreign [6].

\subsection{Social benefits}

From an individual household accounting perspective, $\mathrm{SWH}$ use saves about $\$ 1000$ in discounted water heating costs over a 15-year period. This means families can invest the savings in other critical welfare needs. SWH systems have a payback of just over 4 years for the high-income households. However, payback periods for low-income households are higher at an estimated 7 years and this is mainly due to their lower water heating thermal demand. Families also benefit from the continuity in supply of hot water and reduction of external costs associated with air pollution from wood combustion, paraffin poisoning, fires and burns and wood collection.

For hotels and health institutions, SWH enables the reduction of not only their energy costs but also their maximum demand charges. These savings can then be transferred to either customers, shareholders value or employee welfare. This should help improve competitiveness and customer service.

An additional benefit for all consumers is that they can avoid unplanned expenditure, which comes with energy price fluctuations. By minimising energy purchases, consumers can protect themselves from future energy price hikes while still enjoying full benefits of energy services. Widespread SWH use can result in the creation of an industry that supports the technology employing between 9000 and 15,000 people by 2030 (extrapolated from [40]).

From the wider societal or government perspective, the use of SWHs results in reduced dependence on imported energy and imported equipment (postponement of construction of new generation plants), and significant savings can be made on convertible currency. A SWH scenario can save the country between $\$ 95$ million and $\$ 250$ million over the next 25 years in just the three sectors with respect to the CTPP scenario. Savings in electricity made from water heating can then be made available to other sectors and boost production for the whole economy. The use of scarce foreign currency to finance energy imports deprives the productive sector of inputs and slows down investment. The government, as the custodian of societal public goods, is also in a position to safeguard non-renewable energy resources such as coal used in electricity generation and wood stocks with resultant significant environmental benefits.

SWH would benefit the electricity utility as it reduces peak demand and avoids the expensive dispatch of inefficient plants to meet peak demand. ZESA can also phase out the costly ripple 
control technology and avoid any sophisticated metering that may enable control of domestic consumers. It also enables better system planning when the system load factor is improved.

\section{Discussion}

\subsection{Base case estimates}

From the analysis, it is apparent that most of the water heating thermal demand emanates from the domestic sector. Of the total thermal demand, the domestic sector accounts for $99 \%$ of the demand, hence hospitals and hotels have insignificant contribution to water heating energy demand.

A number of factors are important in understanding and interpreting these results. Firstly, consumption patterns are fairly well understood for the domestic sector and a number of surveys and studies have been conducted in Zimbabwe to assess domestic energy consumption patterns. The same cannot be said about energy consumption in health institutions and the tourism sector. ESMAP [1] surveys estimated consumption patterns in rural health institutions but made no estimates for urban institutions. What is apparent is that health institutions use multiple energy sources for water heating but the characteristics have not been well studied. Faced with these difficulties, we therefore estimated energy demand for water heating in hospitals by assuming that all institutions use electricity for water heating and estimating the demand per hospital bed/patient. We use consumption estimates made in a study conducted in Indonesia at St. Carolus Hospital which indicated that each patient requires about 301 of water a day and average specific electricity use per litre of water of about $0.03 \mathrm{kWh}$ [41]. It may be necessary to confirm such estimates for Zimbabwe. Statistics on the number of hospital beds and bed occupancy are fairly accurate from national health indicator studies and other research activities.

On the other hand demand for hot water in modern hotels is well documented. There are slight variations in estimates of hot water demand ${ }^{8}$ from which average values can be derived. Such average values provide typical hot water demand in tropical countries since hotel services are generally uniform. The estimated specific electricity consumption per litre for several studies reviewed also converges at about $0.03 \mathrm{kWh}$.

However, there are inherent inaccuracies from aggregate demand since we use averaged room occupancy for the entire year but in practice units actually consume more as they remain online even when rooms are empty. Larger hotels using larger boiler units may also be having oversized hot water systems when room occupancy is low. Therefore even if room occupancy is at $41 \%$, actual energy consumption remains high, unless such systems have low standing losses or smart controls.

\footnotetext{
${ }^{8}$ Roditi [42] reports about 80-100 1/room/day, FSEC [43] estimates about $120 \mathrm{l} / \mathrm{room} /$ day including restaurants and laundry.
}

Water heating patterns in the domestic sector are more easily understood, but it may be difficult to generalise since individual systems differ with regards to architecture, installation design, insulation, hot water usage patterns, thermostat setting, position of heating element, ratings, etc. To verify our analysis, we used two methods to estimate water heating demand in the domestic sector and were able to cross check the accuracy of our estimates. The first uses empirical data from the electricity utility statistics and can be assumed to be fairly accurate. Even though demand estimates were extrapolated from 1992, average household consumption has not changed. We also estimated the number of conventional water heating systems based on a 1993 study and compare the empirical data with theoretical estimates. The theoretical $(917 \mathrm{GWh})$ and empirical $(880 \mathrm{GWh})$ estimates agree within $4 \%$ range which we conclude to be a good convergence.

Our theoretical estimates show that each electrical water heater in the high-income households consumes an average $3536 \mathrm{kWh}$ /annum or about $10 \mathrm{kWh} /$ day. This is in agreement with estimates made in other countries. ${ }^{9}$ There is also convergence on our estimates of the number of electrical water heaters installed in 2000 when we compare the estimated average annual electricity use in water heating per household and the estimated consumption per water heater.

Each electrical water heater is estimated to contribute about $1.1 \mathrm{~kW}$ of diversified demand to the electricity winter peak demand while each solar water heater reduce coincident peak demand by $0.7 \mathrm{~kW}$. This figures were estimated from empirical studies conducted over 2 years in 18 households in Florida (US) from the 1982 to 1984 [32]. We justify the use of the Florida figures because of similarities in average ambient temperatures between Zimbabwe and Florida (in the absence of any other credible source). ${ }^{10}$ Temperature is an important element in water heating as the amount of heat required is depended on the temperature of incoming cold water and overall energy demand is dependent on standing losses which are directly related to the ambient temperatures.

For the low-income households, we assumed that $30 \%$ of stove use is to heat water based on studies conducted in Burundi [21]. It is important that further research be conducted in

\footnotetext{
${ }^{9}$ Breakspear [44] measured about $20.6 \mathrm{kWh}$ /day consumption for a highincome household in South Africa (using 2701 of hot water) of which $6.75 \mathrm{~kW}$ were standing losses leaving only $13.65 \mathrm{kWh}$ for actual energy use. Merrigan and Parker [32] measured consumption of 18 family units with average consumption of about 211 1/day and found average consumption for a 3.6 person family to be $8.3 \mathrm{kWh}$ and for 4-person household to be $11.4 \mathrm{kWh}$. These experiments were performed in Florida (US) from 1976 to 1977 before improved insulation was a standard requirement. Basson [45] gave average daily electricity consumption estimates of about $12 \mathrm{kWh}$ for South Africa with peaks in winter of about over $15 \mathrm{kWh}$.

${ }^{10}$ In Florida, annual average temperatures are about $23.5^{\circ} \mathrm{C}$, with a minimum average of $18.8^{\circ} \mathrm{C}$ and a maximum average of $28.1^{\circ} \mathrm{C}$ while in Zimbabwe the mean maximum temperatures range between 22 and $36^{\circ} \mathrm{C}$ in the hot season, mean minimum temperatures range between 10 and $24^{\circ} \mathrm{C}$ in the cool season (for Harare, the annual average temperatures are about $18.1^{\circ} \mathrm{C}$ ) Source: http:// www.worldclimate.com/sources.html: Florida (Flamingo Ranger Station, Monroe County) data derived from 30 years between 1961 and 1990: ZimbabweHarare (Belvedere Station) data derived between 1949 and 1984.
} 
Zimbabwe to verify such assertions including determination of average hot water use per person in the different income groups. There is also need to define the boundaries between water heating and cooking for the groups who use stoves and the possible multiple fuel and device use. For instances, some households use both the conventional water heater and stove or an electric kettle depending on hot water application.

Similarly, health institutions are known to use many energy carriers for water heating. The older and bigger hospitals such as Harare Central Hospital use large coal-fired boilers to heat water for cooking and laundry. Rural institutions are more likely to use a lot of wood fuel depending on accessibility and availability. Our assumption that all medical institutions use electricity for water heating only allows us to estimate the thermal demand in the absence of detailed information and hence further surveys need to be conducted to assess the various energy consumption patterns.

The aggregate coincident winter peak demand due to water heating of $277 \mathrm{MW}$ represents about $13 \%$ of Zimbabwe's national winter peak. This may appear large but estimates in other countries are higher, e.g., Merrigan and Parker [32] estimated that electric water heaters account for about $25 \%$ of the utility winter peak demand in Florida. McDiarmid [20] estimated that water heating in all sectors contribute about $84 \mathrm{MW}$ to peak demand in Zimbabwe. He based his estimate on assumption that total electricity use for water heating in all sectors was about 615 GWh. ${ }^{11}$ Another study [6] indicated that the utility (ZESA) managed to clip off about $7 \%$ of system peak by controlling about 39,000 water heaters during the morning and evening peaks in Harare and Bulawayo. The same study estimates the potential of peak demand shaving to be at least $10 \%$ if additional loads are controlled. Therefore, a $13 \%$ contribution to winter peak demand is well within practical expectations. Of course during warmer days, the diversified demand goes down to about $0.2 \mathrm{~kW} /$ water heater. Unfortunately utilities should be able to supply the winter peak demand without service interruptions and also plan new generation capacity based on probable loss of load during such peaks.

\subsection{Scenarios}

Growth in thermal energy demand for water heating is assumed to be mainly driven by population growth. Since our target group is mainly urban households, we assume demand is driven by household growth as projected in national statistical reports.

Implicitly assumed also is the growth in urbanisation and economy. For the tourism sector, growth in demand is directly related to GDP growth. We assumed that GDP continues to decline until 2005, after which modest economic growth is

\footnotetext{
${ }^{11}$ He assumed that mining uses $0.1 \%$, industry $1 \%$, farming $0.2 \%$, commercial $4.3 \%$, metered households $31.5 \%$ and load limited households $10 \%$ of their electricity for water heating. Additionally, he estimated that water heaters are on for $50 \%$ of the time giving a load of about $140 \mathrm{MW}$ and assuming a diversity factor of $60 \%$ during peak periods, this gives an effective contribution of $84 \mathrm{MW}$ to peak demand.
}

attained. These estimates are not robust, but our results are not much affected because the tourism industry contributes only less than $1 \%$ of the energy demand for water heating.

In the BAU scenario, we assume that all electricity for water heating is imported. In reality, BAU is a combination of locally generated electricity from thermal power stations (32\%) and hydro power stations (29\%) plus about $41 \%$ imported electricity in 2000, see Fig. 1. This could constitute another scenario. However, in this paper we want to illustrate the distinct impacts of each unadulterated trajectory.

We assume in the business as usual scenario that there continues to be excess capacity in the SAPP region. Costs for maintaining transmission lines and the distribution networks are ignored in this case as we assume these activities will be carried out anyway as part of the SAPP backbone infrastructure. However, there may be need to upgrade transmission capacity or build new lines and substations when imports exceed current demand levels. These costs would then count towards Zimbabwe's importing needs. ${ }^{12}$

Costs of electricity traded in the SAPP region are fairly low largely because there is excess capacity. However, South Africa is rapidly electrifying the whole country (about 450,000 connections/annum) [46] and its economy is likely to continue growing in the post-apartheid era. No excess capacity is expected beyond 2007 and unless additional capacity is installed in the region. Additionally, economic growth and investments in neighbouring countries may reduce excess capacity significantly. For instance, the $\$ 2$ billion Mozal aluminium smelter in Mozambique already started consuming $450 \mathrm{MW}$ for the first phase of the project and when completed it will consume a staggering $900 \mathrm{MW}$ as a single investment [47]. This is three to four times the electricity consumption of Mozambique and changes the complexion of power trade in the region. The political situation in Democratic Republic of Congo is unpredictable making it an unreliable long-term source of power. All these pressures on existing capacity may see increases in the costs of traded electricity as scarcity increases. This has to be taken into account when considering a long-term import strategy. Additionally, ZESAs policy has been to limit imports to $20 \%$ of total demand thereby ensuring that there is adequate internal generation to at least meet national demand [6]. ZESA has been forced to go beyond the minimum import limits but long-term strategies may still be based on the minimum import criteria. Therefore Zimbabwe may strategically limit its imports or it may be forced to do so. Whichever outcome, an importing scenario is not viable in the long term as it generally undermines security of supply and put the country at an economic disadvantage.

The coal thermal power plant scenario requires considerable investment in generation capacity (\$639 million over the 25-

\footnotetext{
12 The cost of interconnecting transmission lines is very high, a $330 \mathrm{kV}$ line costs around $\$ 145,000 \mathrm{~km}^{-1}$ and its O\&M costs are around $\$ 9,600 \mathrm{~km}^{-1}$. The $250 \mathrm{~km}$ Cahora Bassa/Bindura $330 \mathrm{kV} / 500 \mathrm{MW}$ interconnector cost about $\$ 36.3$ million while the $400 \mathrm{kV} / 500 \mathrm{MW}$ Matimba Insukamini interconnector cost about $\$ 42$ million. Eighty to eighty-five percent of these costs were foreign related which demand scarce foreign currency [6].
} 
year period). The lack of investment in electricity generation capacity in the past two decades is testimony to the difficulties the country has had in financing the electricity sector. Mangwengwende [48] points out the need for legal and regulatory reform especially tariff reforms, which are considered pre-requisite for private sector involvement and attainment of long-run marginal costing. It is unclear whether current reforms in the electricity sector will attract investment in electricity generation. The national utility ZESA is currently in a poor financial position to make any meaningful investment in power generation. Considerable progress has however been made in grid extension, due mainly to the rural electrification levy imposed on electricity charges. In the CTPP scenario, we assume that coal power plants are built every successive 5 years to meet demand projected in subsequent 5-year period. In reality, it may take more time to build a power plant and therefore investment patterns would have to consider such timedependent critical paths.

Solar water heating is assumed to follow a logistic function of technology diffusion in order not to overestimate the diffusion rates of SWHs (see Fig. 5). We assume that we can only achieve market penetration of $50 \%$. This seems practically achievable, since there already exists at least 73 companies that have capacity to install solar systems and at least 10 of them have been installing SWH systems. Capacity to install SWH depends upon the number of companies, their experience, number of employees and whether the installation is for a new house or replacing an old electrical system. The logistic function therefore fits in well with gradual building of capacity and experience. The shape of the logistic function which defines the rate at which systems are installed can be influenced by policies that accelerate market transformation.

The SWH-II scenario is the cheapest option since it avoids investments in new power generation capacity and relies on imported electricity. However, the importing trajectories are very sensitive to electricity import prices. There are also worries about self-sufficiency and national energy security. Transnational trade can be a victim of global/regional politics and fluctuating prices can make planning difficult.

The SWH-I scenario requires significant investment in internal generation capacity. This plant capacity becomes redundant in the long term, and the excess power can be used elsewhere in the economy. Local generation has an advantage as far as national energy security is concerned, but the foreign components of initial investment costs are around 60-70\%. Maintenance and rehabilitation of plants also involve substantial amounts of foreign currency, for example $86 \%$ of the costs of refurbishing small thermal power plants are foreign [6]. In contrast, $90 \%$ of the components of SWHs are local and only $10 \%$ are foreign related [1].

Water heating consumes about $42 \%$ of domestic energy electricity consumption but this is only $8 \%$ of national electricity consumption. From a utility perspective, ZESA would want to sell more electricity and currently has a program to connect more customers and encourage more electricity usage (the so-called widening customer base and deepening of sales marketing strategy). At the same time ZESA has a program to reduce power (kVA) demand especially by larger customers in an effort to reduce the burden on the electricity system and peak demand capacity requirements. The water heating ripple control is testimony to the concern by the utility to reduce peak demand. It is therefore in the interests of the electricity utility to encourage solar water heating as it improves the problematic domestic load factor, reduce peak demand and still sell electricity during the night when demand is low for industrial production. ZESA would lose money if it dispatched inefficient plants to meet peak demand requirements from the domestic sector because the domestic tariff does not include a maximum demand charge and has generally lower tariffs than the productive sector tariff. Therefore, from a national perspective, water heating is only problematic as far as peak demand requirements are concerned, although energy savings are also important as they relate to depletion of nonrenewable resources and the opportunity costs of electricity, wood fuel and paraffin used.

\section{Conclusions}

In this paper, we demonstrated the importance and significance of water heating in the national energy end-use regime in Zimbabwe and concluded that solar water heating can result in economic, social and environmental benefits for the whole country.

Unlike other renewables, SWH can make a difference in the energy supply on a national level in absolute terms especially with regards to the critical winter peak demand reduction. SWH is also an appropriate technology for developing countries in general as it can be implemented by small- and medium-scale enterprises as is shown by practice in developed nations. Local production of all components is possible with broad-based national smart policies. Investments can be incremental, adaptive and reflexive rather than substantial and unmanageable.

We have shown that water heating in the residential, health and tourism sectors contributes about $13 \%$ of the coincident winter peak demand and accounts for $8 \%$ of final electricity consumed in the country. Total energy consumed for water heating in the three sectors was estimated to be about $9300 \mathrm{TJ}$ and total thermal demand amounted to about 4350 TJ. Sixtyfive percent of this demand was electricity while wood fuel accounted for most of the remaining 35\%. The high-income household subsector accounts for $93 \%$ of the total water heating thermal demand while the tourism and health sectors contribute less than $1 \%$.

Under a business as usual scenario, energy use for water heating in the three sectors will increase by about $109 \%$ to $19,170 \mathrm{TJ}$ in 2030 consisting of $1900 \mathrm{GWh}$ of electricity, 770 kilotonnes of wood fuel and 1.3 million 1 of paraffin. Peak demand is expected to increase by $112 \%$ to $586 \mathrm{MW}$.

If solar water heaters are deliberately introduced in the three sectors, it is possible to save about 104 PJ of final energy use over the period 2005-2030 assuming a 50\% market penetration and a modest diffusion rate. A higher diffusion rate and a higher market penetration results in 54\% savings of the BAU scenario 
or 208 PJ. Solar water heating can also result in discounted cost savings of between $\$ 95$ million and $\$ 250$ million depending on the source of backup electricity. Likewise, quicker market transformation and higher market penetration can result in savings of between $\$ 137$ million and \$297 million.

Between $60 \%$ and $85 \%$ of these costs are foreign related. In contrast, $90 \%$ of the components of SWHs are local and only $10 \%$ are foreign related. Similarly, environmental emissions can decrease by about $58 \%$ with respect to a new power plant scenario.

A solar water heating scenario where backup electricity is imported (SWH-I) is the cheapest option since it avoids investments in new power generation capacity. Concerns about self-sufficiency and national energy security are unimportant with solar water heating in the long term as the country becomes less dependent on imported electricity.

Backup for solar water heating is necessary during off-peak hours when electricity prices are favourable. Peak demand is reduced by $64 \%$ per water heating device and nationally peak demand can be reduced from $13 \%$ to about $5 \%$ with significant benefits to the utility and the whole economy.

Solar water heating would benefit the electricity utility as it reduces peak demand and avoid the expensive dispatch of inefficient plants to meet peak demand.

From an individual household accounting perspective, solar water heating allows discounted cost savings of about $\$ 1000$ over a 15-year period. This means families can invest the savings in other critical welfare needs. Households also benefit from uninterrupted supply of hot water. There are also externalities associated with traditional water heating practices such air pollution, paraffin poisoning, fires and burns.

For hotels and health institutions, solar water heating can bring reduction in their electricity bills which can be transferred to either customers, shareholders value or employee welfare. This should improve competitiveness and improve customer service.

Government, as the custodian of societal public goods, is in a position to safeguard non-renewable energy resources such as coal used in electricity generation and wood stocks with resultant significant environmental benefits. SWH reduces dependence on imported energy such as electricity and paraffin and it can delay the construction of new generation plants. Hence, there are cost savings associated with imported equipment for new generation plants and convertible currency and this is critical for the government. Savings in electricity made from water heating can then be made available to other sectors and boost production for the whole economy. The use of scarce foreign currency to finance energy imports deprives the productive sector of inputs and dampens investment. Widespread use of solar water heaters can result in the creation of an industry and more employment per kilowatt-hour than conventional electricity generation industry.

\section{Recommendations}

To achieve widespread solar water heating dissemination in Zimbabwe, we recommend the development of a broad-based policy framework which includes relevant government departments, the electricity utility ZESA, the private sector, research institutions, financial institutions, support and communitybased groups such as NGOs. Government through the Department of Energy could provide leadership in steering the process. It may be necessary to enlist international leveraging financing to support local financial institutions that may not have experience in financing renewables.

Broad policy strategies which can support alternative energy sources such as solar water heating are already in current government policy, but this political will has not yet been translated into enhanced practical activities. This is probably because of the traditional planning priorities and the fragmentation of efforts to promote renewables. Prevailing macroeconomic conditions have been cited as contributory to stagnation in renewable energy diffusion, but another school of thought may argue that such cost-effective initiatives may assist in the economic recovery process. What is required are conducive and enabling policy instruments crafted in a multistakeholder and interactive framework. This approach enables more ideas to be generated and better strategies to be formulated.

Barriers to the diffusion of renewables are well documented and barrier identification studies have been done including in Zimbabwe. Even though we have shown in this paper that it makes economic sense to invest in SWH, it is clear that the initial investment cost is the major impediment to widespread dissemination. There is therefore need for appropriate and broad-based policy initiatives that removes such impediments and create market transformation for SWH.

It is also recommended that education of potential consumers become central in any strategy to promote SWH. Consumers should be educated on investment decision making, basic technological insights and accessing any facilities for the adoption of such technologies. All stakeholders should do their share of educating the public but community-based organisations and NGOs could take the lead.

Financial instruments are required to push-start the promotion of SWHs. Since the biggest problem is the initial cash outlay, it implies therefore that some form of support or innovative financial mechanisms is necessary to reduce the burden of high upfront costs. These economic instruments should be part of a broader fiscal policy. All key stakeholders should participate in the process and this includes government by instituting fiscal support through incentives and disincentives such as tax and duty reductions for systems and activities related to SWH.

Since investment in SWH entails a transfer of investment responsibilities from public bodies (in Zimbabwe the national utility, ZESA and indirectly the government) to private individuals, the benefits that accrue to these public bodies can be shared and translated into some form promotional schemes such as subsidies for the private individuals.

Additionally, there is need for support for innovative private sector and research institutions who wish to undertake development of local components which in the long term may be copied by other private companies. It is therefore risky 
for the private sector to invest heavily in technology development when they may lose the 'first-mover' advantage in the long term. Again it is also the role of government to reward innovators, set market rules and share the technology risks as custodian of public good. International 'green' finance and other 'clean energy'-related investment mechanisms could also be useful in this respect. The electricity utility can also develop further incentives by for example offering long-term loan repayment through the electricity bill. ZESA is already investing in costly ripple control and therefore can save by assisting in a SWH financial scheme.

Financial institutions such as building societies/mortgage lenders can also participate by offering long-term loans at mortgage interest rates for water heating system retrofits for old houses and as part of the mortgage for new houses. Lysen [49] summarises some innovative financing schemes compiled by the Utrecht Centre for Energy Research.

Normative and regulatory instruments are also required to support promotion of SWHs. There is a lot of scepticism when it comes to renewables and their potential to displace traditional energy carriers. This is based on misconceptions, bad experiences and uncertainties about real performance. We recommend the provision of some form of guarantee system tied to the supplier. This will force companies to produce high quality systems. Installers should be accredited and registered to an institution in the same way that other trades such as medical doctors have registries. Consumers should be educated about how to make such choices, and again a communicative instrument plays a key role.

We also recommend the drafting of nationally agreed standards for solar water heaters within the multi-stakeholder framework, taking into account different sectoral needs. Other countries such as Israel, Greece and Cyprus have had success with SWH promotion by some legislative measures such as making it obligatory for every building to install a SWH system [50]. This may be feasible for new houses, but may be difficult and expensive to enforce for old houses. Such an instrument may also face a lot of resistance and backfire on the whole initiative. Other countries such as India have also started to legislate compulsory SWH installation on all new institutional buildings that use large quantities of hot water.

Finally, given the potential of SWH evaluated in this paper, it is apparent that SWH can play a significant role in alleviating the energy and economic problems in Zimbabwe.

\section{Acknowledgements}

We gratefully acknowledge Stephen Karekezi of the African Energy Policy Research Network for providing assistance during the study formulation. We are grateful for the assistance provided by Norbert Nziramasanga of Southern Centre for Energy and Environment with respect to data and comments he provided. We also thank Ralph Tirivanhu of the Department of Energy, Zimbabwe for his comments and critique on the initial proposal for this study. We are further grateful to the following people for the comments, information and critique they gave during the study: Bert Brouwer of Brouwer Energie Consult BV; Egbert Gramsbergen of Gramsbergen Solar; Anton Schwarzlmuller of Domestic Solar Water Heating Ltd.; Carol Sibanda of Solahart Zimbabwe; Derrick McDiarmid of Solamatics and R. McDiarmid \& Co. Ltd.; and Masunda Chimhamhiwa of the Zimbabwe Sun Hotels, Resorts and Lodges.

\section{References}

[1] ESMAP. Zimbabwe rural electrification study. ESMAP Report 228/00. Joint UNDP/World Bank Energy Sector Management Assistance Programme; 2000.

[2] SAPP. Southern African Power Pool Statistics 2005/6; 2006.

[3] Kayo D. Power sector reforms in Zimbabwe: will reforms increase electrification and strengthen local participation? Energy Policy 2002;30:959-65.

[4] SAPP. Southern African power pool: annual report 2001/2. Harare; 2002.

[5] IMF. Zimbabwe: selected issues and statistical appendix. IMF Country Report No. 03/225. International Monetary Fund, Washington, DC; 2003.

[6] Mawire M, Kapuya ET, Harlen RM, Dube I. Demand side management: "a Zimbabwean perspective". Paper presented at the domestic use of energy conference, Cape Technikon; 1998.

[7] Hove T, Göttsche J. Mapping global, diffuse and beam solar radiation over Zimbabwe. Renew Energy 1999;18:535-56.

[8] Habitat. Cities in a globalising world. Global report on human settlements United Nations Centre for human settlements. London: Earthscan Publications; 2001.

[9] UNIDO. The reform of the power sector in Africa. Sustainable energy regulation and policy making for Africa. Vienna: UNIDO; 2007.

[10] AFREPREN/FWD. Making the African power sector sustainable. Nairobi: UNEP/UNECA; 2005.

[11] IMF. Zimbabwe: selected issues and statistical appendix. IMF Country Report No. 05/359. Washington, DC; October 2005.

[12] World Bank. World development indicators database, http://devdata. worldbank.org/query/; 2006.

[13] SAIIA. The Zimbabwe economy: how has it survived and how will it recover? SAIIA Report No. 30. The South African Institute of International Affairs; 2002.

[14] IEA. Energy balances for non-OECD countries. 2001-2002, 2004 ed., Paris: IEA Statistics, OECD; 2004.

[15] Campbell BM, Vermeulen SJ, Mangono JJ, Mabugu R. The energy transition in action: urban domestic fuel choices in a changing Zimbabwe. Energy Policy 2003;31:553-62.

[16] ZESA. Customer information system and statistics. Harare: ZESA; 2007.

[17] JICA. The OECD/DAC's new development strategy. Report of the issuewise study committee for Japan's official development assistance. vol. 3 . Country studies; 1998.

[18] Hansen K, Chapman G, Chitsike I, Kasilo O, Mwaluko G. The costs of hospital care at government health facilities in Zimbabwe with special emphasis on HIV/AIDS patients. Health Policy Plan 1999;14:432-40.

[19] ZTA. Tourism trends and statistics: Zimbabwe. Harare: Zimbabwe Tourism Authority; 2001.

[20] McDiarmid D. Solar water heating: an economic option for utilities. In: Proceedings of "The African Utility Conference'; 1998 [ISES 1998].

[21] Katihabwa J. Solar hot water for household and institutional use in Bujumbura, Burundi. In: AFREPREN African energy: issues in planning and practice. Zed Books; 1990. p. 25-30.

[22] SADC TAU, UNDP. FINESSE: Zimbabwe country report. Joint UNDP/ Southern African Development Community Technical and Administrative Unit, Luanda; 1997.

[23] Karekezi S. Renewable in Africa-meeting the energy needs of the poor. Energy Policy 2002;30:1059-69.

[24] Mashange K. The turbulent liquid fuel industry in Zimbabwe: options for resolving the crisis and improving supply to the poor. Energy Policy 2002;30:1047-55.

[25] ZESA. Consumer energy audit records; 2001 [unpublished]. 
[26] Maya RS, Nziramasanga N, Muguti E, Fenhann J. UNEP greenhouse gas abatement costing studies. Zimbabwe country study. Phase II. Zimbabwe: Southern Centre for Energy \& Environment, Riso National Laboratory, Department of Energy; 1993.

[27] DHV, KEMA, Lysen, Van Dien \& Co. Long term energy planning study for Aruba. vol. 1. Final report. Ministry of Economic Affairs, Aruba; 1988.

[28] Maya RS, Mhlanga AP, Nziramasanga N, Mutyasira M. Implementation of renewable energy technologies-opportunities and barriers. Zimbabwe country study. Southern Centre for Energy \& Environment/UNEP Collaborating Centre on Energy and Environment; 2001.

[29] UNEP. Climate change mitigation in Southern Africa. Methodological development, regional implementation aspects, national mitigation analysis and institutional capacity building in Botswana, Tanzania, Zambia and Zimbabwe. Phase 1. Riso, Denmark: UNEP; 1995.

[30] AEE, EVA, BMWA. Energy technologies for sustainable development. Cooperation between Austria and developing countries; 2003. p. 6-7.

[31] Canwood WN. State of the art in solar water heater development in South Africa. In: Eberhard A, Williams A, editors. Renewable energy resources and technology in Southern Africa. Energy Research Institute, Elan Press; 1988.

[32] Merrigan T, Parker D. Electrical use, efficiency, and peak demand of electric resistance, heat pump, desuperheater, and solar hot water systems. Presentation at American Council for an energy efficient economy, Florida Solar Energy Centre, August 1990; 1990.

[33] Batidzirai B, Zhou P. In: Maya RS, editor. Options for greenhouse gas mitigation under power pooling in Southern Africa. Harare: Mond Books; 1999. p. 1999.

[34] Davis M, Horvei T. Handbook for the economic analysis of energy projects. Development Bank of Southern Africa/DMEA/Eskom; 1995.

[35] AIT (Centre for Energy-Environment Research \& Development). NEPO/ DANCED investigation of pricing incentives in a renewable energy strategy: assessment of potential use of solar thermal system in Thailand; 1998.

[36] Johansson TB, McCormick K, Neij L, Turkenburg W. The potentials of renewable energy. Thematic Background Paper. In: International Conference for Renewable Energies, Bonn; 2004.
[37] Hove T. Energy delivery of solar thermal collectors in Zimbabwe. Renew Energy 2000;19:495-511.

[38] Batidzirai B. Potential for solar water heating in Zimbabwe. Report NWSI-2004-13. Department of Science, Technology and Society, Utrecht University, Utrecht, The Netherlands; 2004.

[39] Dube I. PV for rural areas-the power utility (ZESA) Zimbabwe's experience. Renew Energy 2001;24:517-20.

[40] Greenpeace and EPIA (European Photovoltaic Industry Association). Solar generation: electricity for over 1 billion people and 2 million jobs by $2020 ; 2001$.

[41] Brouwer GB. Solar hot water system. St. Carolus Hospital, Jakarta, Indonesia. Van Heugten Consulting Engineers. Netherlands; 1990.

[42] Roditi D. Catching the sun. Solar water heaters for hotels. Renew Energy World 2002;5(September-October (5)):118-27.

[43] FSEC (Florida Solar Energy Centre). Energy savings for a typical Carribean hotel; 2003.

[44] Breakspear D. Residential water heating systems - theoretical and real usage efficiencies. Proceedings of the 5th Domestic Use of Electrical Energy Conference, Cape Town, 1998. p. 241-244.

[45] Basson JA. Results of an integral solar water heater research/demonstration project. In: Eberhard A, Williams A, editors. Renewable energy resources and technology in Southern Africa. Energy Research Institute, Elan Press; 1988.

[46] EDRC. Rural electrification in South Africa. Research summaries from EDRC. Energy \& Development Research Centre, University of Cape Town; 1998.

[47] Hoover R. Damming the Zambezi for aluminium. Proposed dam a "power play" to gain control of upstream dam? In international rivers network. World Rivers Rev 2001;16:10-1.

[48] Mangwengwende SE. Tariffs and subsidies in Zimbabwe's reforming electricity industry: steering a utility through turbulent times. Energy Policy 2002;30:947-58.

[49] Lysen EH. Energy financing for sustainable development. Utrecht Centre for Energy Research; 2002. p. 13-16.

[50] EECA (Energy Efficiency \& Conservation Authority) and SIA (Solar Industries Association). Review of overseas initiatives that have been taken to increase the uptake of solar water heating. New Zealand: EECA; 2002. 